\title{
HOW TO GET INTERNATIONAL CONSTRUCTION PROJECTS DELIVERED ON TIME: FROM CHINESE CONTRACTORS' PERSPECTIVE
}

\author{
Hongxin SUN ${ }^{1}$, Wenzhe TANG ${ }^{*}$, Colin F. DUFFIELD ${ }^{2}$, \\ Lihai ZHANG ${ }^{2}$, Felix Kin Peng HUI ${ }^{2}$ \\ ${ }^{1}$ Tsinghua University, Institute of Project Management and Construction Technology, State Key Laboratory \\ of Hydroscience and Engineering, New Hydraulic Building, 100084 Beijing, China \\ ${ }^{2}$ Department of Infrastructure Engineering, The University of Melbourne, Victoria 3010, Australia
}

Received 3 January 2021; accepted 6 December 2021

\begin{abstract}
Chinese international construction projects are seriously delayed, which creates the potential for instability in its rapidly growing share of global contracting markets. A greater understanding of the reasons behind the challenges confronting international contractors is urgently required such that improvements can be developed that ultimately will benefit many countries. This study aims to investigate the time performance of international projects in developing countries and to explore the root causes of time overrun. Based on both quantitative and qualitative analysis of 112 case study projects, collected from 12 of the largest Chinse state-owned enterprises (SOEs), this study identifies the distinctive characteristics of three types of projects (late, acceptable, early) classified based on their time performances. It is established that time performance is significantly related to the contractor's adaptability and project complexity. The results reveal the root causes of construction delays in international project delivery, which provides a structured and in-depth understanding of both internal and external time performance influential factors. The above findings provide sound basis for guiding practitioners in choosing appropriate strategies to improve project time performance, such as encouraging cross-cultural dialogues, integrating global resources and establishing long-term global partnerships with stakeholders.
\end{abstract}

Keywords: time performance, international construction, project management, construction delays, project environment, developing countries, Chinese contractors.

\section{Introduction}

As China is becoming more and more actively involved in international affairs, the Belt and Road Initiative (BRI) as conceived in 2013, has drawn increasing worldwide attention. As of April 2019, China had signed 187 cooperation agreements with 131 countries and 30 international organizations from Asia, Africa, Europe, Oceania and Latin America. From 2013 to 2018, the initiative attracted over USD 80 billion of foreign investment with the value of new international construction contracts reaching USD 500 billion. The World Bank (2019) predicted a trade increase of 2.8-9.7\% for countries situated at the 6 economic corridors under the BRI. This increase equates to an increase in overall global trade of $1.7-6.2 \%$.

Motivated by the growing infrastructure demand along the transport corridors, more and more Chinese construction enterprises have entered the international contracting market. During this period the Engineering News-Record
(ENR), has reported that in 2018, 69 Chinese companies had become top 250 international contractors. This places Chinese contractors as the most dominant in the global market. A comparison between Chinese and other national contractors in international revenue and market share is shown in Figures 1a and $1 b$.

Chinese contractors are the only group expanding and they have become the first to exceed USD 100 billion. Moreover, except for Latin America, Chinese contractors are the dominate market participants in every jurisdiction (Figures 1a and $1 \mathrm{~b}$ ). In spite of the remarkable progress inspired by the BRI, notable failures such as Poland's A2 project indicate that there are still numerous challenges being encountered in project delivery. Compared with domestic construction projects, international projects are exposed to a large variety of uncertainties and external risks, since the business has become much more compli-

*Corresponding author. E-mail: twz@mail.tsinghua.edu.cn

Copyright $\odot 2022$ The Author(s). Published by Vilnius Gediminas Technical University

This is an Open Access article distributed under the terms of the Creative Commons Attribution License (http://creativecommons.org/licenses/by/4.0/), which permits unrestricted use, distribution, and reproduction in any medium, provided the original author and source are credited. 
cated than ever (Gunhan \& Arditi, 2005; Ramcharran, 1998; Semple et al., 1994). Javernick-Will and Scott (2010) and Liu et al. (2020) ascribed the failures of international projects to the inadaptation to environmental differences in multi-national cooperation. Mahalingam and Levitt (2007) further pointed out that serious time overrun may occur, if the differences were not paid enough attention to.

As one of the most common problems in international projects, time overrun (Ahmed et al., 2002; Ameh et al., 2010) can cause serious negative impacts on project performance and the parties of the contract (Abd El-Razek et al., 2008; Marzouk et al., 2008). Faridi and El-Sayegh (2006) surveyed that $50 \%$ of the construction projects in United Arab Emirates experienced time overrun. In Saudi Arab, Al-Sultan (1989) found that $30 \%$ of the public projects were completed on time, while the figure in Malaysia was only $8 \%$ (Rahman et al., 2012). However, there is limited research on causes of construction delays across different countries and practical strategies to avoid time overrun in international project delivery. Based on case study analysis of construction projects undertaken by Chinese contractors, this study aims to investigate the actual time performance and root causes of time overrun of international construction projects in developing countries. The assessment and comparison of time performance was made with the help of quantitative analysis techniques, while the root causes of time overrun were explicitly interpreted based on qualitative assessments and expert

a) International revenue of ENR top 5 international contractors from 2013 to 2017 (USD billion)

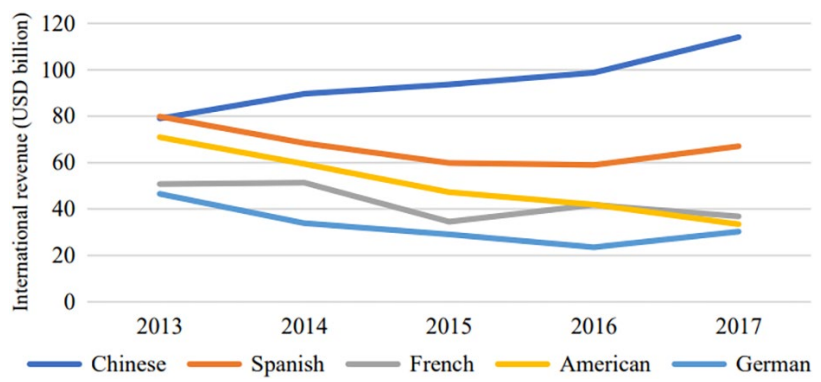

b) Market shares of ENR top 5 international contractors in underdeveloped regions in 2017

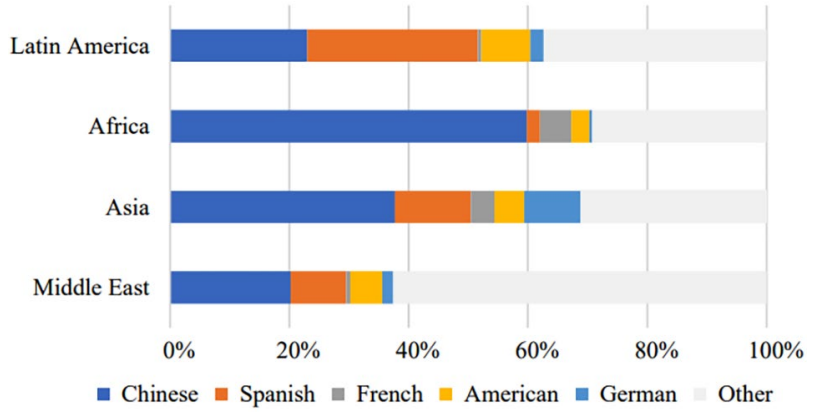

Figure 1. International revenue and market share of Engineering News-Record (ENR) top 5 international contractors (Engineering News-Record, 2014, 2015, 2016, 2017, 2018) opinions from focus group interviews. The study is of both theoretical value to a broad and in-depth perception of relationships among time performance, international project management and project environments, and practical value to guiding successful and timely project delivery in developing countries.

\section{Time performance}

Time, together with quality and cost, are identified as three most common criteria for project success (Wright, 1997). A significant number of literatures highlighted the necessity of timely delivery (Latham, 1994; Rwelamila \& Hall, 1995). Cox et al. (2003) even identified "on-time completion" as the most important indicator of project performance, as it facilitates the control of cost and quality (Male, 2003). Delayed handover can not only cause great trouble to several dimensions of performances (Gonzalez et al., 2014), but also undermine the recognition from the client and the competitiveness of the contractor (Orozco et al., 2014).

The duration of a project is usually the most common index to measure time performance. Complexity arises when consideration is given to changes as the baseline may change. From the perspective of the investor, the original commitment is generally accepted as the benchmark albeit that there remain different views (Kaka \& Price, 1991). In this study, the time performance was measured based on the original estimates, i.e. with the following equation (Othman et al., 2006):

$$
\mathrm{TPI}=\frac{\text { Actual contract duration }}{\text { Original contract duration }}
$$

where TPI $=1$ means that the project is exactly delivered on time. The original contract duration is the planned construction time stipulated in the contract, while the actual duration is calculated from official commencement to final completion. Numerous studies have been conducted on the causes of time overrun in construction projects, as shown in Table 1.

The management and governance of a project, called the managerial factor, is most commonly cited as the cause of time overruns in international projects (refer Table 1). Specific aspects of this criterion mainly include: poor site supervision, impropriate communication patterns and improper scheduling. Owner-related issues rank as the second most common and this is comprised of late payment, inadequate instructions and inaccuracy of bidding files. Financial and resources-related factors are also frequent reasons for construction delays, constituted by insufficient raw materials supply, low bid price and late delivery of materials and equipment. It is also established that in either Asian or African countries, technical factors do not appear to be the major constraint to successful delivery. Apart from the causes mentioned in Table 1, there are also scholars believing that project attributes describing project scope and complexity, such as project cost and project type, are also significant influential factors of time overrun in international projects (Anastasopoulos et al., 2012; Talukhaba, 1999). 
Table 1. The main causes of time overrun in developing countries

\begin{tabular}{|c|c|c|c|c|c|c|c|c|c|c|}
\hline \multirow[b]{2}{*}{ Country } & \multirow[b]{2}{*}{ Literature } & \multicolumn{9}{|c|}{ Factors } \\
\hline & & $\begin{array}{l}\text { Owner- } \\
\text { related }\end{array}$ & $\begin{array}{l}\text { Design- } \\
\text { related }\end{array}$ & $\begin{array}{l}\text { Contrac- } \\
\text { tual }\end{array}$ & $\begin{array}{l}\text { Labour- } \\
\text { related }\end{array}$ & \begin{tabular}{|c|}
$\begin{array}{c}\text { Manage- } \\
\text { rial }\end{array}$ \\
\end{tabular} & \begin{tabular}{|c|}
$\begin{array}{c}\text { Resource- } \\
\text { related }\end{array}$ \\
\end{tabular} & $\begin{array}{c}\text { Techni- } \\
\text { cal }\end{array}$ & $\begin{array}{l}\text { Finan- } \\
\text { cial }\end{array}$ & Natural \\
\hline \multicolumn{11}{|c|}{ African countries } \\
\hline Egypt & $\begin{array}{l}\text { Abd El-Razek et al. } \\
\text { (2008); Marzouk et al. } \\
(2008)\end{array}$ & $\sqrt{ }$ & $\sqrt{ }$ & & & $\sqrt{ }$ & $\sqrt{ }$ & & $\sqrt{ }$ & $\sqrt{ }$ \\
\hline Ghana & \begin{tabular}{|l|l} 
Frimpong et al. (2003) \\
\end{tabular} & $\sqrt{ }$ & & & & $\sqrt{ }$ & $\sqrt{ }$ & $\sqrt{ }$ & $\sqrt{ }$ & \\
\hline Kenya & \begin{tabular}{|l|} 
Seboru (2006); \\
Talukhaba (1999)
\end{tabular} & $\sqrt{ }$ & $\sqrt{ }$ & & & $\sqrt{ }$ & & & & $\sqrt{ }$ \\
\hline Nigeria & $\begin{array}{l}\text { Adekunle and Ajibola } \\
\text { (2015); Odeyinka et al. } \\
\text { (2004) }\end{array}$ & $\sqrt{ }$ & $\sqrt{ }$ & & $\sqrt{ }$ & $\sqrt{ }$ & $\sqrt{ }$ & & $\sqrt{ }$ & $\sqrt{ }$ \\
\hline Tanzania & $\begin{array}{l}\text { Kikwasi (2012); } \\
\text { Sambasivan et al. } \\
\text { (2017) }\end{array}$ & $\sqrt{ }$ & $\sqrt{ }$ & $\sqrt{ }$ & $\sqrt{ }$ & $\sqrt{ }$ & $\sqrt{ }$ & & & $\sqrt{ }$ \\
\hline Zambia & Kaliba et al. (2009) & $\sqrt{ }$ & $\sqrt{ }$ & $\sqrt{ }$ & $\sqrt{ }$ & $\sqrt{ }$ & $\sqrt{ }$ & & $\sqrt{ }$ & \\
\hline \multicolumn{11}{|c|}{ Asian countries } \\
\hline Bahrain & Hasan (2014) & $\sqrt{ }$ & & & $\sqrt{ }$ & $\sqrt{ }$ & $\sqrt{ }$ & & & \\
\hline Cambodia & \begin{tabular}{|l|}
$\begin{array}{l}\text { Santoso and Soeng } \\
(2016)\end{array}$ \\
\end{tabular} & $\sqrt{ }$ & & & $\sqrt{ }$ & $\sqrt{ }$ & $\sqrt{ }$ & & $\sqrt{ }$ & $\sqrt{ }$ \\
\hline Iran & $\begin{array}{l}\text { Asnaashari et al. } \\
\text { (2009); Khoshgoftar } \\
\text { et al. (2010) }\end{array}$ & $\sqrt{ }$ & & $\sqrt{ }$ & & $\sqrt{ }$ & $\sqrt{ }$ & $\sqrt{ }$ & & $\sqrt{ }$ \\
\hline Kuwait & $\begin{array}{l}\text { Al Tabtabai (2002); } \\
\text { Koushki and Kartam } \\
(2004)\end{array}$ & $\sqrt{ }$ & & & & $\sqrt{ }$ & & & & \\
\hline Lebanon & $\begin{array}{l}\text { Mezher and Tawil } \\
\text { (1998) }\end{array}$ & $\sqrt{ }$ & $\sqrt{ }$ & $\sqrt{ }$ & & $\sqrt{ }$ & & & $\sqrt{ }$ & \\
\hline Malaysia & $\begin{array}{l}\text { Rahman et al. (2012); } \\
\text { Sambasivan and Soon } \\
\text { (2007) }\end{array}$ & $\sqrt{ }$ & $\sqrt{ }$ & $\sqrt{ }$ & $\sqrt{ }$ & $\sqrt{ }$ & $\sqrt{ }$ & & $\sqrt{ }$ & \\
\hline Pakistan & Haseeb et al. (2011) & $\sqrt{ }$ & & & & $\sqrt{ }$ & $\sqrt{ }$ & & $\sqrt{ }$ & $\sqrt{ }$ \\
\hline Qatar & $\begin{array}{l}\text { Gunduz and } \\
\text { AbuHassan (2016) }\end{array}$ & $\sqrt{ }$ & & & $\sqrt{ }$ & $\sqrt{ }$ & $\sqrt{ }$ & & & \\
\hline $\begin{array}{l}\text { Saudi } \\
\text { Arabia }\end{array}$ & $\begin{array}{l}\text { Al-Kharashi and } \\
\text { Skitmore (2009); } \\
\text { Alotaibi (2018) }\end{array}$ & $\sqrt{ }$ & $\sqrt{ }$ & & $\sqrt{ }$ & $\sqrt{ }$ & & & $\sqrt{ }$ & \\
\hline Thailand & $\begin{array}{l}\text { Ogunlana et al. (1996); } \\
\text { Toor and Ogunlana } \\
\text { (2008) }\end{array}$ & $\sqrt{ }$ & $\sqrt{ }$ & & & $\sqrt{ }$ & $\sqrt{ }$ & & $\sqrt{ }$ & \\
\hline Turkey & $\begin{array}{l}\text { Arditi et al. (1985); } \\
\text { Kazaz et al. (2012) }\end{array}$ & $\sqrt{ }$ & $\sqrt{ }$ & & & $\sqrt{ }$ & $\sqrt{ }$ & & $\sqrt{ }$ & \\
\hline Uganda & Alinaitwe et al. (2013) & $\sqrt{ }$ & & $\sqrt{ }$ & & $\sqrt{ }$ & & & $\sqrt{ }$ & $\sqrt{ }$ \\
\hline UAE & $\begin{array}{l}\text { Faridi and El-Sayegh } \\
(2006)\end{array}$ & $\sqrt{ }$ & $\sqrt{ }$ & $\sqrt{ }$ & $\sqrt{ }$ & $\sqrt{ }$ & & & & \\
\hline Vietnam & $\begin{array}{l}\text { Kim et al. (2008); Le- } \\
\text { Hoai et al. (2008) }\end{array}$ & $\sqrt{ }$ & & & & $\sqrt{ }$ & $\sqrt{ }$ & $\sqrt{ }$ & $\sqrt{ }$ & \\
\hline
\end{tabular}

Despite the detailed studies on contributing causes of time overrun, yet the underlying reasons as to why the outcomes differ from projects delivered in different countries remain. Overall, previous studies are concentrated on a country-based view with efforts trying to identify the causes of construction delays in a specific country, for example, Kenya (Seboru, 2006). However, due to increasing expansion of international contractors into developing markets and requirements for diversified international cooperation, a huge gap in research on time performance evaluation of international projects and strategies to manage diverse external environments and consequent risks is in urgent need to be filled in. Thus, this study was carried out to obtain a holistic view of timely delivery in dynamic complex environments of developing countries. The objectives of the study are to evaluate the time performance of international construction projects in developing countries and to explore the main causes of time overrun for those projects. Improvements that would assist the time performance of international contractors working in developing countries are further recommended based on the survey results. To achieve the objective, both quantitative and qualitative analysis were conducted. 


\section{Research method}

The first step of the study is to investigate the time performance of Chinese contractors working in developing markets and to identify the root causes of time overrun. Therefore, a mixed approach of document review and focus group interviews were adopted to provide a rich source of qualitative and quantitative evidence for time performance analysis (Gillham, 2000; Yin, 2017). The quantitative data were mainly collected from document review and then analysed using multiple correspondence analysis (MCA) and one-way analysis of variance (ANOVA), to evaluate time performance of 112 international construction projects (Objective 1). The qualitive data were collected from focus group interviews, the participants of which were from the aforementioned 112 cases to reveal the main causes of time overrun (Objective 2). The research strictly complied with the research ethics requirements of Tsinghua University.

\subsection{Data collection}

To gather enough samples for data analysis, 3 research trips were organized from 2016 to 2017 to visit 12 outstanding international contractors. All the 12 enterprises satisfy three criteria: 1) total assets over 100 million USD; 2) overseas industrial experience over 10 years; 3 ) willing to participate in the survey for insights of improvements. 112 completed international construction cases were collected and then processed using document review to identify the project metrics that are considered of most relevance to construction delays, including project location (Kadry et al., 2017), delivery method (Chen et al., 2011), contractor size (Cho et al., 2009), technical standard (Lei et al., 2017), project designer, project type, project cost and duration (Anastasopoulos et al., 2012; Talukhaba, 1999). These metrics were manually extracted from both paper and electronic documents comprised of internal reports, contracts, technical specifications and announcements of mile stones. Furthermore, the data were sent back to the 12 enterprises to reconfirm its accuracy. The distribution of 112 cases is displayed in Figures 2a-2c.

As shown in Figures $2 \mathrm{a}-2 \mathrm{c}$, the 112 construction projects were located in 5 continents, 73 in Africa, 24 in Asia, 11 in Latin America, 3 in Europe and 1 in Oceania, basically matching the current market distribution of Chinese international contractors. Over $50 \%$ of the projects are transportation projects, such as roads and bridges, while the rest is approximately equally divided by general projects and power projects. Less than $10 \%$ of the cases are large-scale infrastructure projects. The majority of the projects are relatively smaller, with a total cost lower than USD 10 million. To explore the root causes of construction delays in these underdeveloped regions, 12 focus groups were also organized during the 3 research trips, each consisting 6-12 volunteers from the 112 projects, who were professional managers with rich international experience in project delivery. The profile of focus groups and 83 participants is displayed in Table 2.

In total, 83 professionals took part in the focus group interviews, in which 27 participants are project managers with the rest constituted by electrical engineers (11), construction managers (10), financial managers (9), contract managers (9), HSE managers (7), HR managers (5), design managers (3) and quality managers (2). With an average industrial experience over 10 years in international project delivery in 20 countries, the interviewees are of typical representativeness to reflect the current challenges faced with by global contractors aiming at developing markets. According to Bhandari and Hallowell (2021), focus group, as an expert opinion technique aiming at face-to-face discussion and argument, is inevitably subject to cognitive biases. Biases such as bandwagon effect, dominance effect, observer expectancy, conservatism in belief revision and framing effect should be carefully managed to guarantee the validity and reliability of the resulting data. To avoid dominance effect and conservatism in belief revision, the participants selected were unfamiliar with each other and willing to share their opinions for self-improvement. As for observer expectancy and framing effect, all 12 focus group interviews were only given a general theme "international construction practice in developing countries: featuring time performance" and a few heuristic questions. The moderator was mainly in charge of warming up and starting conversations without giving any of personal tendencies towards certain topics. To deal with bandwagon effect, the participants were encouraged to share the anecdotes working abroad and their opinions on construction delays in international projects, and even debate with other participants. All the conversations were carefully recorded and confidentially preserved to make the participants feel safe and free to express themselves, as suggested by Anderson et al. (1998). The records were dis- a) Project location

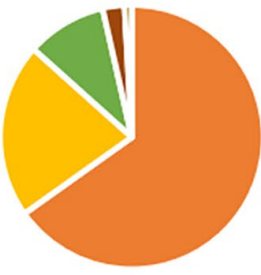

b) Project type

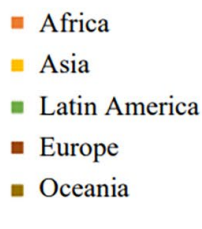

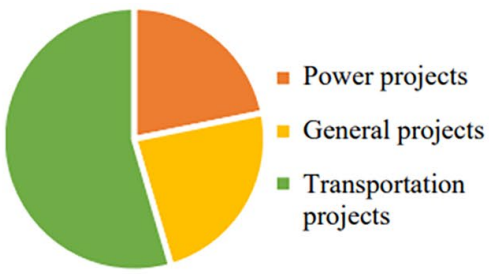

c) Project cost

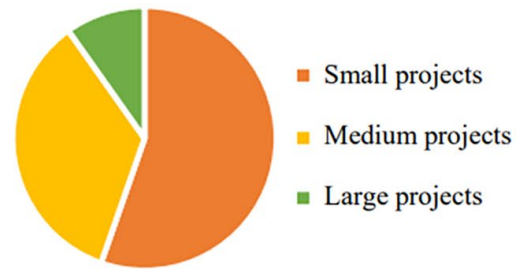

Notes: Small projects: cost <USD 10 million; Medium projects: between USD 10-100 million; Large projects: >USD 100 million

Figure 2. Distribution of 112 international construction cases collected from research trips 
Table 2. Profiles of focus groups and 83 participants

\begin{tabular}{|c|c|c|c|c|c|}
\hline No. & $\begin{array}{l}\text { Time \& } \\
\text { location }\end{array}$ & $\begin{array}{l}\text { Number of } \\
\text { focus groups }\end{array}$ & $\begin{array}{l}\text { Number of } \\
\text { participants }\end{array}$ & Roles of participants & Distribution of participants \\
\hline \multirow{3}{*}{$\begin{array}{l}\text { Trip } \\
1 \#\end{array}$} & $\begin{array}{l}\text { 2016/10/20 } \\
\text { Guiyang }\end{array}$ & 2 & 12 & $\begin{array}{l}\text { Design manager } \\
\text { Project manager }\end{array}$ & $\begin{array}{l}\text { Mauritius } \\
\text { Cambodia }\end{array}$ \\
\hline & $\begin{array}{l}\text { 2016/10/24 } \\
\text { Chengdu }\end{array}$ & 2 & 12 & $\begin{array}{l}\text { Financial manager } \\
\text { - Construction manager }\end{array}$ & $\begin{array}{l}\text { - Bangladesh } \\
\text { - Pakistan }\end{array}$ \\
\hline & $\begin{array}{l}\text { 2016/10/27 } \\
\text { Changsha }\end{array}$ & 2 & 12 & - Contract manager & E Fiji \\
\hline \multirow{3}{*}{$\begin{array}{c}\text { Trip } \\
2 \#\end{array}$} & $\begin{array}{l}\text { 2016/11/17 } \\
\text { Kunming }\end{array}$ & 1 & 8 & $\begin{array}{l}\text { Project manager } \\
\text { HSE manager }\end{array}$ & $\begin{array}{l}\text { Congo } \\
\text { Sudan }\end{array}$ \\
\hline & $\begin{array}{l}\text { 2016/11/19 } \\
\text { Chengdu } \\
\end{array}$ & 1 & 7 & $\begin{array}{l}\text { Financial manager } \\
\text { - Construction manager } \\
\text { Electrical en nineer }\end{array}$ & $\begin{array}{l}\text { Cameroon } \\
\text { Ecuador } \\
\text { Gabon }\end{array}$ \\
\hline & $\begin{array}{l}\text { 2016/11/22 } \\
\text { Chengdu }\end{array}$ & 1 & 7 & $\begin{array}{l}\text { Contract manager } \\
\text { Quality manager }\end{array}$ & $\begin{array}{l}\text { Mali } \\
\text { Sri Lanka }\end{array}$ \\
\hline \multirow{3}{*}{$\begin{array}{l}\text { Trip } \\
3 \#\end{array}$} & $\begin{array}{l}2017.04 .17 \\
\text { Tianjin } \\
\end{array}$ & 1 & 8 & $\begin{array}{l}\text { Project manager } \\
\text { HSE manager }\end{array}$ & $\begin{array}{l}\text { Qatar } \\
\text { Angola }\end{array}$ \\
\hline & $\begin{array}{l}2017.04 .20 \\
\text { Xian }\end{array}$ & 1 & 10 & $\begin{array}{l}\text { - Financial manager } \\
\text { - HR manager }\end{array}$ & $\begin{array}{l}\text { Ethiopia } \\
\text { Botswana } \\
\text { Chad }\end{array}$ \\
\hline & $\begin{array}{l}\text { 2017.04.23 } \\
\text { Zhuozhou }\end{array}$ & 1 & 7 & $\begin{array}{l}\text { Electrical engineer } \\
\text { - Contract manager }\end{array}$ & $\begin{array}{l}\text { - Belize } \\
\text { Venezuela }\end{array}$ \\
\hline
\end{tabular}

tributed to the participants for reconfirmation to exclude the potential biases and to show that all their opinions were highly valued. It is worth mentioning that nearly all participants expressed their gratitude to our organization of focus groups, which provided a valuable opportunity for peer learning. The keywords and phrases regarding root causes of time overrun in international construction projects were later extracted from the transcribed records for further statistical analysis.

\subsection{Data analysis techniques}

To evaluate the actual time performance of the 112 international construction project, data analysis techniques combining MCA and ANOVA were adopted. Widely used in social science studies, MCA can be viewed as principal component analysis applied to the complete disjunctive table formed from a set of nominal categorical data to detect and represent its underlying structure (Ali et al., 2018). Associations between the variables were measured by calculating the chi-square distance, allowing highdimensional data to be visualized in a low-dimensional (normally two-dimensional) Euclidean space (Richards \& van der Ark, 2013). The distance between two points in the coordinate axes reflect the degree of their similarity with each other (Jobson, 2012), thus revealing the potential relationships among the project metrics which could not be directly observed (Dhalmahapatra et al., 2019).

Then, ANOVA was performed to validate the results of MCA and compare the time performance of projects among different categories. Differentiated from t-test, ANOVA can be utilized to compare the difference among means of two or more groups (Hossain et al., 2019). As a parametric test, it should comply with three assumptions: 1) normal distribution; 2) independence and comparabil- ity; 3) homogeneity of variance (Molugaram et al., 2017). If the F-test statistics (Variability across groups/variability within groups) exceed 1 , it means that there is at least one group mean that is significantly different from the others (Smalheiser, 2017). MCA and ANOVA were conducted with the help of SPSS 21.0.

\section{Results and analysis}

\subsection{Measuring time performance}

As presented in introduction part, time performance index (TPI) is usually used to measure time performance, where TPI $=1$ means that the project is completed exactly on time. According to Merrow (2011), the project should be regarded as a failure if the index exceeds $125 \%$. Therefore, the critical value of distinguishing whether the time performance of a project is acceptable is determined as 1.25 . In this regard, $67.9 \%$ of the projects are seriously delayed with an average TPI of 1.53 and an average schedule slippage of 11.21 months. To adopt MCA to evaluate the time performance of projects with different attributes, the qualitative metrics should be categorized first, as shown in Table 3.

A two-dimensional MCA was conducted for planar visualization of eight variables (see Table 3), where 35.0\% and $23.1 \%$ of the variation can be explained by dimension 1 (eigenvalue, 3.151; inertia, 0.350) and dimension 2 (eigenvalue, 2.079; inertia, 0.231), separately. The results and interpretation are shown in Figures 3a-3b.

As displayed in Figure 3a, three circles are formed around three ideal points, representing "early projects", "acceptable projects" and "late projects", respectively. The project metrics within the same circle have the best possibility to correlate with each other. For instance, the dot 
"PL3" (Latin America) is situated in the "late projects" circle, meaning that Latin American projects are most likely to slip the original contract time. Reversely, the dot "PL2" (Asia) is located in the "early" circle, indicating that Asian projects more possibly completed ahead of time. The results show that time performance is sensitive to metrics including project type, project location, project designer, technical standard, project cost and contractor size, as these dots appear most in the three circles.

The implications of the joint plot (Figure 3a) were illustrated in Figure 3b. Dimension 1, the horizontal axis, is labelled as "adaptation level" based on the metrics of technical standard, project location and project designer, reflecting the contractor' adaptability. The dots "TS2" (foreign standards), "PL3" (Latin America) and "PD2" (foreign designer), together with the "late projects" circle, are situated on the left two quadrants of Figure 3a, meaning that the project could be delayed if its contractor has to cope with unfamiliar environments or cooperative partners. Oppositely, the dots "TS1" (Chinese standards), "PL2" (Asia), "PD1" (Chinese designer) and the circles of "early projects" and "acceptable projects" are located on the right two quadrants of Figure 3a, representing that the project could be timely delivered as its conditions and environments much resemble domestic projects, to which the contractor could be well adapted.

Overall, the high ratio of delayed projects $(67.9 \%)$ reveals that Chinese contractors are faced with serious challenges in the first scenario, where prompt adjustments are urgently required for quicker adaptation to unfamiliar environments, especially as new entrants in a developing market. The results of focus group interviews also confirm the inadaptation experienced by Chinese contractors in countries outside Asia, which is mainly derived from distinct cultural and social backgrounds. For example, language is the first barrier to a contractor aiming at a

Table 3. Categories of project metrics for MCA

\begin{tabular}{|l|l|l|}
\hline \multicolumn{2}{|c|}{ Indexes } & \multicolumn{1}{c|}{ Project metrics } \\
\hline \multicolumn{3}{|c|}{ Categories } \\
\hline CS & Contractor size & CS1 $=<5$ billion yuan, CS2 $=5 \leq \sim<10$ billion yuan, CS3 $=\geq 10$ billion yuan, total assets \\
\hline DM & Delivery method & DM1 $=$ Design-Build, DM2 $=$ Design-Bid-Build, DM3 $=$ Turnkey \\
\hline PC & Project cost & PC1 $=<$ USD 10 million, PC2 $=$ USD $10 \leq \sim<100$ million, PC3 $=$ USD $\geq 100$ million \\
\hline PD & Project designer & PD1 $=$ Chinese designer, PD2 $=$ Foreign designer \\
\hline PL & Project location & PL1 $=$ Africa, PL2 $=$ Asia, PL3 $=$ Latin America \\
\hline PT & Project type & PT1 $=$ Power, PT2 $=$ General, PT3 $=$ Transportation \\
\hline TS & Technical standard & TS1 $=$ Chinese standards, TS2 $=$ Foreign standards, TS3 $=$ Mixed standards \\
\hline & & Project performance \\
\hline & Time performance & Early $=$ Rd $\leq 1$, Acceptable $=1<$ Rd $\leq 1.25$, Late $=$ Rd $>1.25$, TPI \\
\hline
\end{tabular}

a) Joint plot of category points

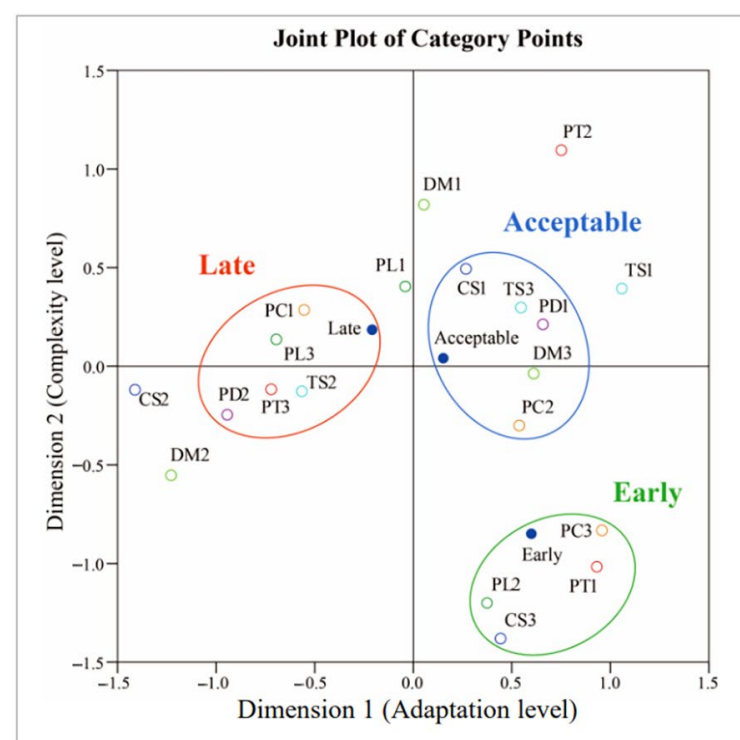

Notes: the full terms of abbreviations refer to Table 3. b) Implications of joint plot

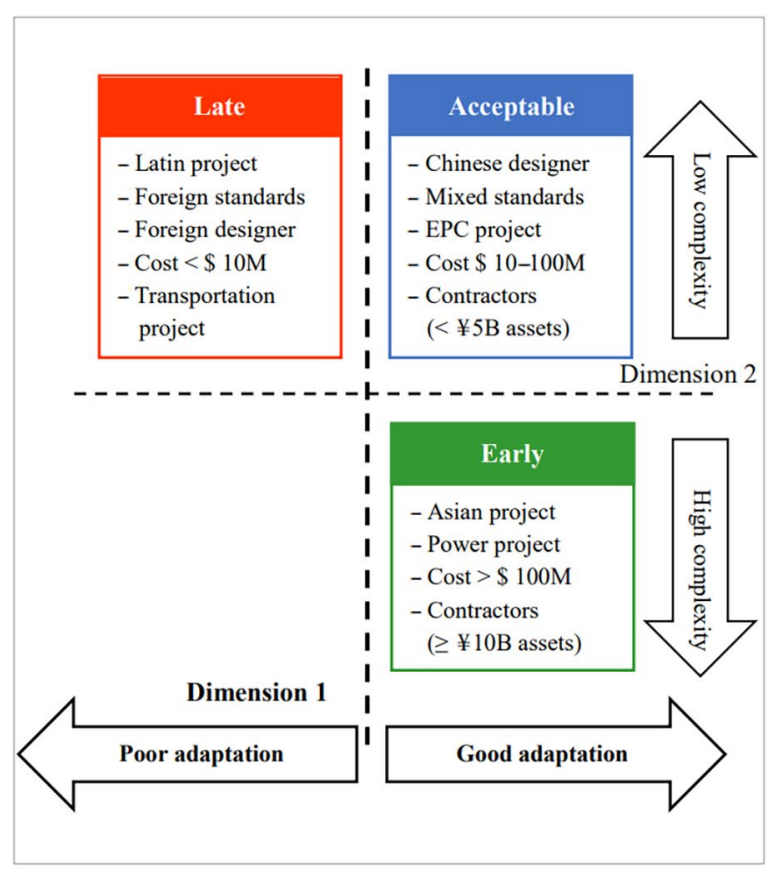

Figure 3. Multiple correspondence analysis using data collected from case study 
foreign market. Unlike in Asian countries where the contractors mainly use English to communicate, projects in Latin America usually choose Spanish or Portuguese as the official working language, which could bring unneglectable inconvenience in technical interface and daily communication among the participants, resulting in the low efficiency in inter-organizational activities.

Dimension 2, the vertical axis, is labelled as "complexity level" based on metrics including project cost and project type (Talukhaba, 1999), reflecting the sophistication of an international project. Dots "PT3" (transportation projects), "PC1" (low-cost projects), "PC2" (mediumcost projects) within the two circles "acceptable projects" and "delayed projects" are situated in the upper parts of the coordinate in Figure 3a, while the dots "PT1" (power projects) and "PC3" (large-cost projects) within the "early projects" circle are located in the lower part in Figure 3a. A surprising finding that Chinese contractors perform even better in project with greater sophistication is drawn from the Dimension 2, illustrating that technical capability is the ace in the hole for Chinese contractors due to the abundant experience and resources accumulated in past decades of construction practice. The successful completion of mega infrastructure, such as the Three Gorges Dam and Hong Kong-Macau Bridge, stimulated the cultivation of a multitude of professionals with multi-disciplinary backgrounds and the advance in technologies needed for mega project implementation.

Despite the global reputation of advanced technologies, the failure to timely acclimatize to changing complex environments in developing countries seems to have become a major constraint for Chinese contractors to take that technical advantage, considering the high proportion of construction delays. To test the significance of time performance difference among categories in Figures 3a-3b, one-way ANOVA was conducted as below.

\subsection{Comparing time performance among different categories}

One-way ANOVA was used to compare the means among two or more categories. As mentioned in data analysis techniques, this parameter test should follow three basic assumptions, normality, comparability and homogeneity of variance. To comply with the assumptions, the dataset of time performance index (TPI) must be properly transformed first. According to the recommendation of IBM (2020), for datasets with positive skew (e.g., extreme large values of TPI) or datasets that represent a ratio (TPI $=$ actual contract duration/original contract duration), the reciprocal transformation $y=1 /(x+1)$ is an ideal choice. The reason of using $y=1 /(x+1)$ instead of $y=1 / x$ is that there are also extreme small values approaching zero. Normality tests were performed both before and after the transformation, as displayed in Table 4.

After reciprocal transformation, the new dataset TPIt passed both Kolmogorov-Smirnov test $(0.099>0.05)$ and Shapiro-Wilk test $(0.155>0.05)$, meaning that the require-
Table 4. Normality test results before and after normal transformation

\begin{tabular}{|l|c|c|}
\hline \multicolumn{1}{|c|}{ Significance } & $\begin{array}{c}\text { Kolmogorove-Smirnov } \\
\text { test }\end{array}$ & $\begin{array}{c}\text { Shapiro-Wilk } \\
\text { test }\end{array}$ \\
\hline $\begin{array}{l}\text { Before } \\
\text { transformation (TPI) }\end{array}$ & 0.000 & 0.000 \\
\hline $\begin{array}{l}\text { After transformation } \\
\mathrm{TPI}_{\mathrm{t}}=1 /(\mathrm{TPI}+1)\end{array}$ & 0.099 & 0.155 \\
\hline
\end{tabular}

Notes: $\mathrm{P}$ value $>0.05$ represents that the dataset complies with normal distribution.

ment for normal distribution has been satisfied. What is also worth mentioning is that higher values of TPIt represent better time performance, completely opposite to the meaning of TPI, due to reciprocal transformation. The homogeneity of variance can be examined using Levene test, which can be conducted together with ANOVA with the help of SPSS. All the indexes in Table 3 were tested with only four, project location, project designer, project cost and project type, passed both Levene and ANOVA tests (significant at $\mathrm{p}<0.05$ ). The results are depicted in Figures $4 \mathrm{a}-4 \mathrm{~d}$.

The results of Figure 4a reveal that Chinese contractors achieve significantly better time performance in Asia $(+0.074$, significant at $\mathrm{p}<0.05)$ and Africa $(+0.056$, significant at $\mathrm{p}<0.05)$, both compared with that in Latin America. Doing business in Asia means fewer language barriers and potential conflicts due to similar social and cultural backgrounds. Besides, delivery of domestically procured electrical and mechanical equipment and raw materials is faster and more convenient, making it the best in time performance. As for Africa, Chinese contractors are holding over $60 \%$ of African contracting markets (refer to Figure $1 \mathrm{~b}$ ) because of early entry and decades of devotion. Past experience could be referred to when doing projects in African countries. In contrast, the market share of Chinese contractor in Latin American is less than $30 \%$ and inadaptation to its social and political environments still exists. A project manager from the focus group interviews claimed that strikes are far more common in Latin America than in Asia or Africa, because project staff are more easily viewed as "outsiders" as a consequence of completely different religious beliefs and cultural traditions.

The results of Figure $4 \mathrm{~b}$ indicate that Chinese contractors achieve significantly better time performance working with Chinese designers $(+0.33$, significant at $\mathrm{p}<0.05)$, compared with the scenario of working with foreign designers, which is attributed to the difference of technical standards and design methodology, as confirmed by the focus group interviews. Despite foreign designers' proficiency in international standards, poor constructability of design options might arise because of their unawareness of the technical strength possessed by Chinese contractors. Insufficient incorporation of contractors' feedback into the design process could result in design variation or design rework, causing significant delays to original construction schedule. 
a) Project location

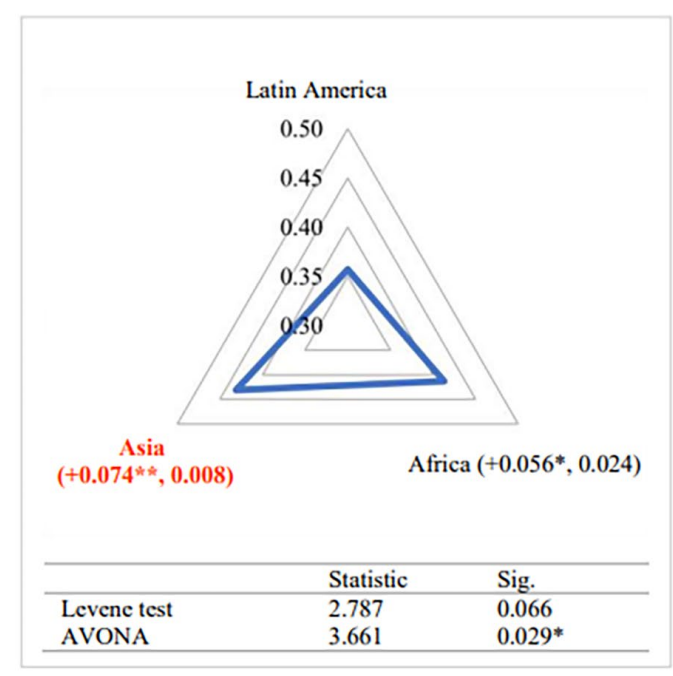

c) Project cost

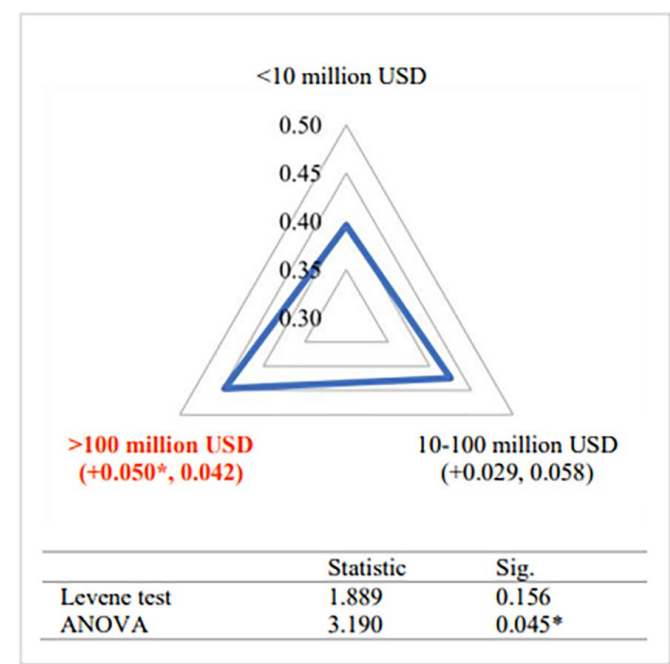

b) Project designer

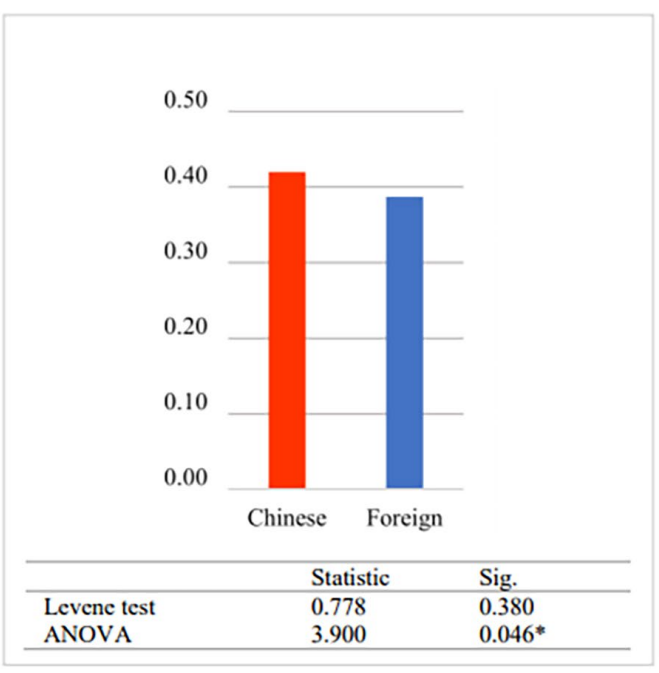

d) Project type

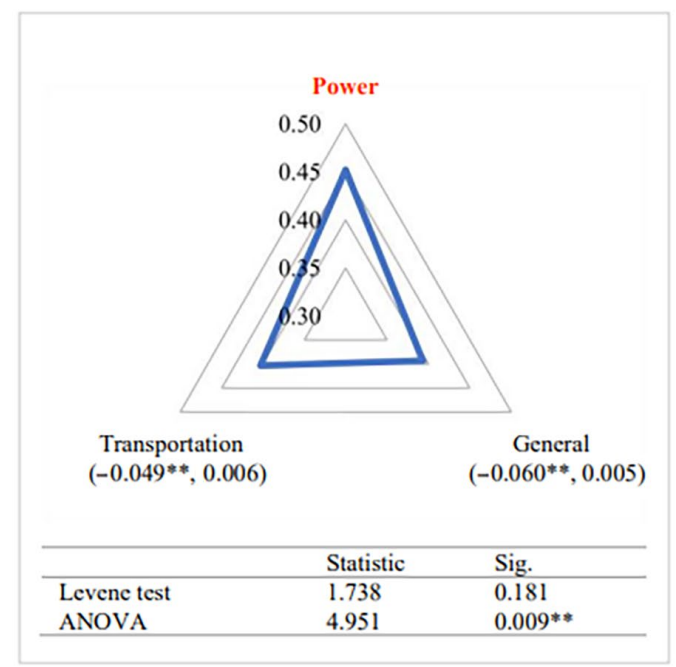

Notes: 1) P values of Levene test $>0.05$ represents that the dataset complies with homogeneity of variance; $2)^{* *}$ represents that significance level $<0.01$, ${ }^{\star}$ represents that significance level $<0.05$; 3) The red coloured category has better time performance compared with others.

Figure 4. One-way variance analysis of project time performance using data collected from case study

Coordination efficiency between foreign designers and Chinese contractors should be promoted via forging a partnership based on trust and open communication. Both results of Figure $4 \mathrm{a}$ and Figure $4 \mathrm{~b}$ strongly support the implication of Dimension 1 in Figures $3 a-3 b$ that inadaptation to unfamiliar environments and cooperative partners is still a major challenge for international contractors in timely project delivery as a new entrant in a developing market.

Figure 4c illustrates that Chinese contractors perform significantly better in large-scale projects $(+0.050$, significant at $\mathrm{p}<0.05)$ and slightly better in medium-sized projects $(+0.029$, significant at $\mathrm{p}<0.1)$, in contrast with small-scale projects. The contributing reasons lies in not only that Chinese contractors have excellent expertise in delivering large-scale projects, but also that the output produced by management and construction activities per unit input of manpower, materials, equipment and money is beyond comparison of small-sized projects.

The results of Figure 4d illustrate that Chinese contractors achieve the best time performance in power projects in contrast with general projects $(-0.060$, significant at $\mathrm{p}<0.01)$ and transportation projects $(-0.049$, significant at $\mathrm{p}<0.01)$. The underlying reasons rest with not only the wealth of experience and technologies inherited from previous power projects, such as complex hydropower projects in Southwest China, but also the unique characteristic of power projects which normally have a longer construction period in comparison with general and transportation projects. Generally, power projects are long-term projects with greater technical complexity which requires enormous involvement of both proficient technicians and multi-disciplinary management talents. The long contract duration can accommodate the project 
team with enough time for multiple participants to adapt to one another in management style and communication patterns at early stage, thus establishing an integral coordination mechanism based on trust during the rest of time. This adaptation period at the early stage will eventually be reimbursed by the following continuous improvement of interface efficiencies of inter-organizational activities. However, the circumstance does not fit with general or transportation projects due to their relatively shorter contract time. The project might already come to an end before the participants are finally compatible with each other in working towards mutual goals.

In sum, the results of statistical tests verify the findings from the correspondence analysis and provide a more in-depth perception of current project performances of international contractors in developing markets. Numerous challenges are still faced by international contractors in managing the risks resulted from stakeholders and external environments to deliver the project on time. As is stated by a road project manager from Venezuela, whose project was surrounded by 5 villages, public attention was constantly attracted on the adverse environment effects of the project since launched. Twice suspension of 2 weeks each were compulsorily required by the government, despite the good efforts of the project team. Such disturbance to the original construction plans causing serious delays repeatedly happened in international project delivery with its underlying causes and effective coping strategies needed for clarification. To explore the root causes of delays in developing countries, the analysis of evidence from focus group interviews was conducted.

\subsection{Exploring root causes of international construction delays}

Time performance comments from the participants were carefully recorded during the focus group interviews. Keywords and phrases summarizing the root causes of construction delays were extracted from the transcribed interview records. Later, those keywords and phrases were further classified into 9 categories based on their logical relations. The results are shown in Figure 5.

All causes displayed in the sunburst chart were categorized into two types:

1) management-related factors (76): interface management (31), human resources management (22), design management (16) and procurement management (7);

2) environment-related factors (102): cultural environment (23), social environment (22), natural environment (21), technical environment (20) and legal environment (16).

Of all factors, interface issue among different participants is perceived as the most frequent (mentioned 31 times) cause of construction delays in international project delivery, especially the poor communication with other project participants. As stipulated by a road project manager from Madagascar, things become particularly intractable when conflicts arise between the contractor and the consulting engineer. It took him half a year to get the planning and drawings finally approved by the French engineer, while the original contract time was only 16 months.

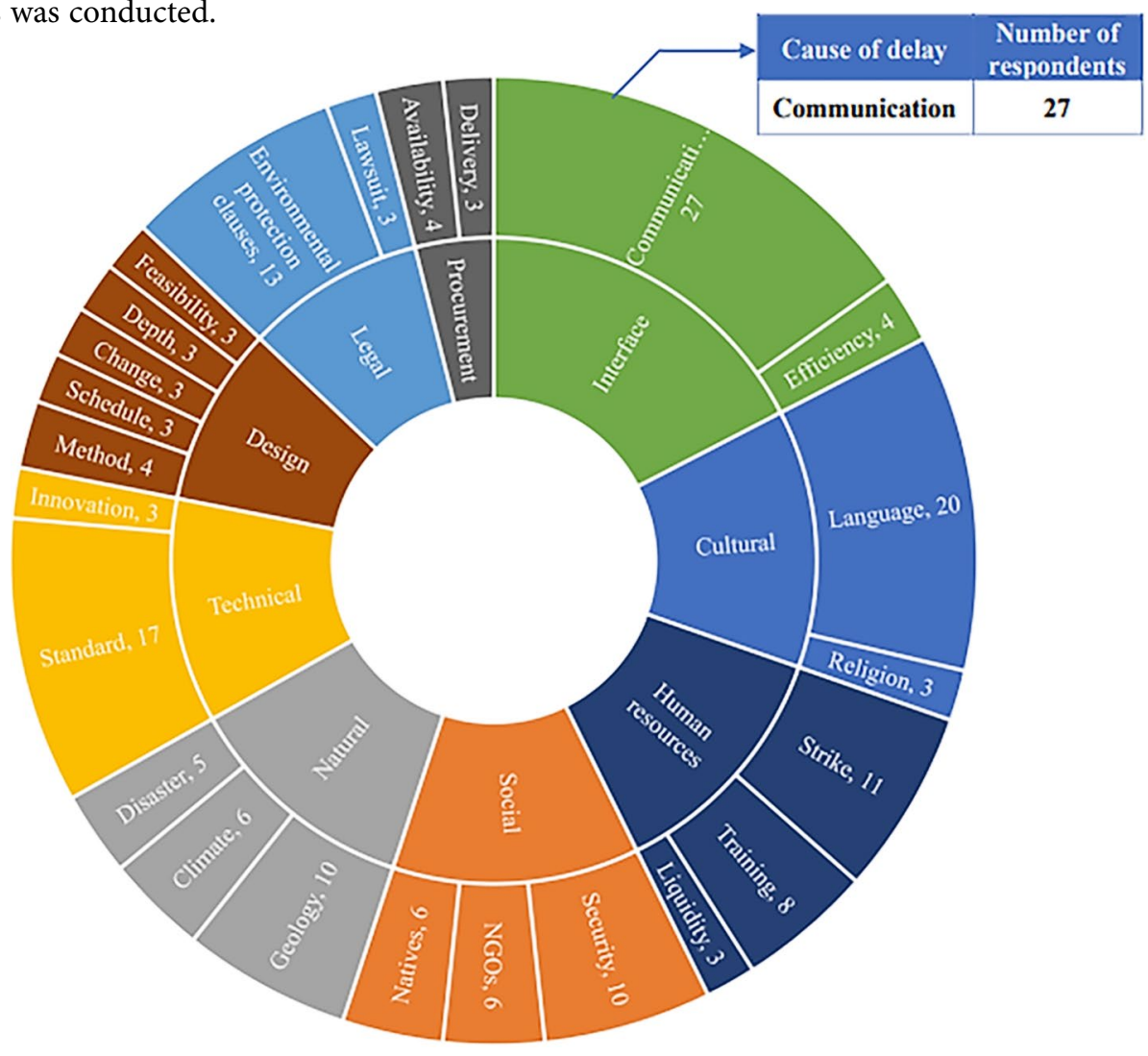

Figure 5. Sunburst chart describing the causes of time overrun through analysis of data obtaining in focus groups 
The project was once suspended because the engineer claimed that the distance between two warning boards on the construction site failed to meet the requirements of HSE plans. Another specific example mention was that of a pipe installation. The contractor had to request a referential letter from a renowned professor to convince the consulting engineer that the installation method was secure and feasible. The whole process lasted nearly a month. Such kinds of interface issues usually result from the difference of technical standards in principles and methods, demanding sufficient communication between the participants to understand and adapt to each other.

Apart from interface problems, poor human resources management is also a major source of time overrun, especially when it comes to the management of local labours. As introduced by a road project manager from Kenya, crashing and working overtime were hardly inevitable in construction projects, which might become the trigger of industrial strikes. As a devastating but common problem in international project delivery, strikes could cause both direct and indirect huge time loss by interrupting the original construction schedule. To rest a strike, contractors usually choose to increase the remuneration, which should not be considered as a prior option. It is believed by the majority of the interviewees that the deeper reason behind a strike is the "misunderstanding" caused by the divergence in cultural traditions and religious beliefs, indicating that management deficiencies might derive from the influence of external environments.

As confirmed by expert opinions, environment-related factors (mentioned 102 times) account for even more causes of construction delays than management-related factors (76 times). Cultural difference is the most frequently mentioned (language 20 times, religion 3 times) factor causing time overrun. A general engineer complained that nearly half of the time was wasted in translating when signing the contract, leaving so little time for technical staff to study the detailed clauses and specifications. The risks brought by insufficient understanding of contracts could be materialized later, resulting in serious time overrun via rework.

Second to cultural factors, social environment was mentioned 22 times (social security 10 times, locals 6 times, NGOs 6 times) among all environment-related factors. Unlike domestic projects, untraditional safety is a major concern in international project delivery, especially in countries or regions with high geopolitical risks. A project manager on vacation from his project in Pakistan referred to a suspension as long as 6 months as a consequence of violent attacks. A "road open day" was set up by the government to prevent violent events, meaning that only on this day of the week were vehicles permitted to pass for transportation of equipment and materials, seriously disturbing his original construction plan. In addition to social security, public voices from residents and NGOs can also add unmeasurable pressure on timely delivery. A project manager from an Indonesia road project shared his experience that the project was first suspended and then terminated because fierce opposite campaigns were regularly held by both local and international organizations, forcing the government to cancel the project. As he stated, projects in remote areas are favoured by the management team as a consequence of less public attention.

Just as there are always two sides to the story, doing projects in remote areas sometimes means higher risks of natural disasters. Unstable geological conditions, extreme climate and unforeseeable natural disasters were respectively mentioned 10, 6 and 5 times as the root causes of time overrun. Extremely weather, such as months of rainy days, could not only lead to a direct time loss but also interrupted the original schedule by affecting traffic to enter the site and soil moisture content. Two project managers from Tanzania and Mauritius joked themselves as "guerrillas" in rainy seasons, who had to grip every minute to restart the construction tasks during the temporary breaks between the showers. The positive aspect is that seasonal patterns are predictable for earlier preparation. Unforeseeable geological and hydrological conditions could result in catastrophic impacts on time performance. A design manager talked about her experience in hydropower engineering in Pakistan, where the local geological conditions are not suitable for building concrete dams. It cost the contractor a whole year to cope with seepage problems after the completion of main works, highlighting the great necessity of pre-investigations before official commencement.

Although the technical capabilities of Chinese contractors are distinguished, the issue of using foreign technical standards is still perceived as a primary source of construction delays. Through decades of practice in large construction projects, the reputation of Chinese contractors' advanced technologies is globally accepted. However, things are different when using foreign standards. For example, there are values in Chinese standards that can be adopted in design work of domestic projects. When the contractor is required to perform the task using foreign standards, it is hard to figure out the exact difference of the value in the two standards in short time, as a multitude of tests might have to be performed to establish a reliable conversion relation. What is more difficult is to explain the difference of the value to the consulting engineer who is unfamiliar with Chinese technical standards. A housing project manager complaint about his first entrance into Sudan market. The consulting engineer insisted on the necessity of a detailed calculation sheet of the luminance and dynamics of a lamp purchased from China, which took days of efforts for the electrical engineer to learn local electric product standards from the very beginning.

In summary, international contractors are experiencing serious construction delays as a result of both deficient internal management and inadaptation to external project environments. A deeper understanding of external environments, such as cultural backgrounds, public attitudes, technical standard differences is urgently needed to strengthen the resistance of the project team to external risks and to improve the interface efficiency in inter-organizational activities. 


\section{Recommendations}

Existing researches mainly concentrate on a country-based view with efforts trying to identify the causes of construction delays in a specific country, for example, Kenya. Managerial factors, as most scholars pointed out, are the main causes of time overrun (Kaliba et al., 2009; Ogunlana et al., 1996; Walker, 1995). Simultaneously, control measures were proposed to improve time performance by refining management techniques and procedures, such as effective strategic planning (Akinsiku \& Akinsulire, 2012; Frimpong et al., 2003), complete final design (Kikwasi, 2012; Pourrostam \& Ismail, 2011) and strict site supervision (Seboru, 2015), which are of limited value to guiding current construction practice in global markets. As more and more international contractors are entering developing countries, a systematic view should be presented to analyze the risks induced by fast changing political and economic environments. Based on a global perspective, this study revealed that the root cause of construction delays in international project delivery is not only the deficiency in internal management, but also the inadaptation of contractors to external environments in developing countries that are dynamic and changeable. To improve project time performance, a sufficient understanding of complex environments and sophistication of stakeholders is required for more precise risk control and decisionmaking. Distinguished from previous studies, strategies featuring international cooperation to help the contractors better acclimatize into local environments are proposed to improve project time performance in developing markets, as displayed in Figure 6.

To accelerate the adaptation into external environments, a thorough and in-depth pre-investigation on local market conditions should be conducted. As is learnt from focus group interviews, there is at least a 6- month period for the contractor to mobilize after being awarded the contract, which is a perfect chance for international contractors to investigate and analyze market supply conditions, technical standard difference, import and export regulations to get fully prepared before commencement. A sufficient understanding of external contexts is of great essence to preventing the materialization of risks that may result in cost or time overruns. An example supporting this finding is a bridge project in Ecuador. After winning the bid, the design team reconducted a detailed geological investigation and discovered that the original culvert design could not meet the drainage requirements. In rapid response, the design was altered as a double-span bridge and later approved by the owner before official commencement, successfully avoiding a potential huge loss. Apart from pre-investigations, the involvement of experienced international firms is also an ideal strategy. As a firm supporter in international cooperation, the project manager of a Sudan EPC project chose to work with a German designer to deal with the difficulties of using DIN standards (German Institute for Standardization). Similar occasions happened in a Fiji hydropower project. The design wind speed of transmission lines was stipulated as $90 \mathrm{~m} / \mathrm{s}$ by the contract. However, due to the climate, wind speed over $38 \mathrm{~m} / \mathrm{s}$ in mainland China is rare phenomenon, let al.ne $90 \mathrm{~m} / \mathrm{s}$. The expected cost and time needed for doing experiments and carrying out a feasible design was unbearable as a consequence of tight schedule and limited budget. Thus, working with an Australian design company who already had a good command of A/NZ standards was apparently a prior choice to control time and cost. In brief, international cooperation features the complementary advantages of different participants and is of great significance to global contractors in risk control and smooth implementation, especially as new entrants in an unfamiliar country.

As indicated by findings from focus groups, one of the root causes of construction delays is the inadaptation to complex external contexts. In order to acclimatize more quickly into local environment, active cross-cultural dia-

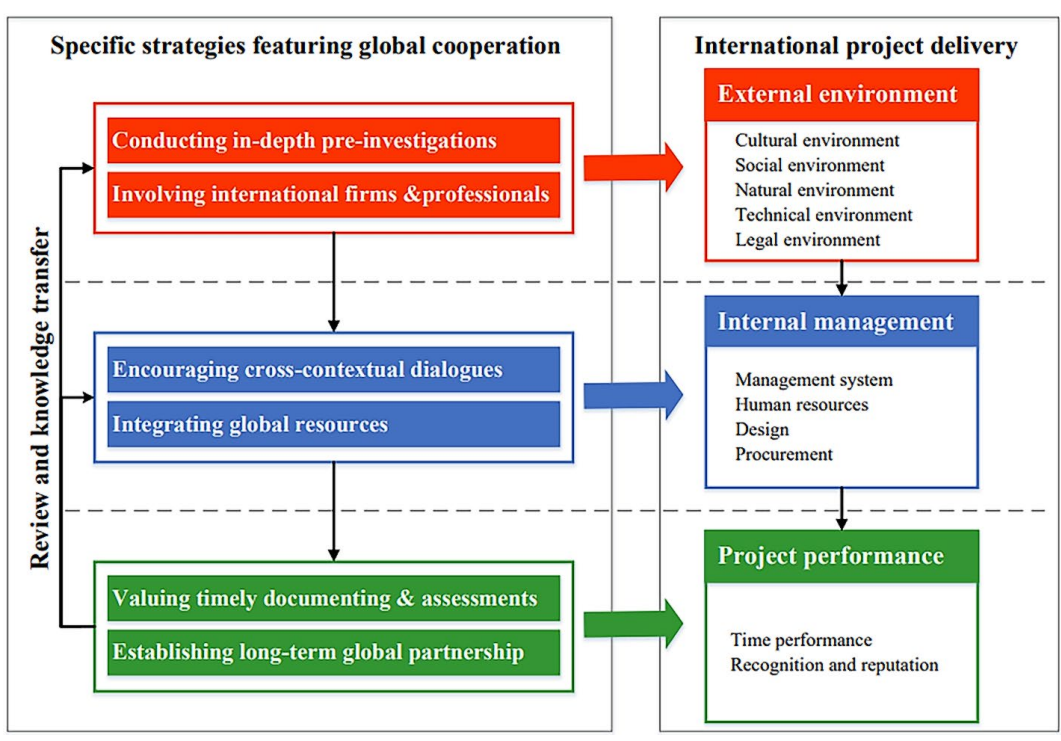

Figure 6. Strategies on improving time performance of international construction projects 
logues with other native participants should be encouraged. In a hydropower project in Gabon, a regular seasonal coordination meeting was held among the general contractor, the owner, the consulting engineer and the designer to discuss major technical difficulties and interface issues. The meetings could also establish a channel for mutual learning from each other in advanced technologies and management methods. Moreover, cross-cultural conversations can happen in interpersonal relationships as well. A typical example is a road project in Ecuador. The project team kept the tradition of inviting all project staff to watch movies together on the construction campus after an entire day of hard work. The Spanish films and Chinese films were shown in turns for entertainment. Trustful friendships among project staff with different cultural backgrounds was gradually established, which was also of great benefits to improving time performance through the promotion of interface efficiency in daily inter- and intraorganizational activities.

Integration of global resources is also a fundamental task when the quality or the quantity of local products cannot meet the demand. The project manager from Fiji began to seek cooperation opportunities with international suppliers since equipment and materials purchased at home often encountered delays in transportation and customs clearance. After careful choices of suppliers with good reputation, a series of long-term procurement contracts were signed. Pylons and power cables were imported from India, and the steel bars were imported from Taiwan, with full consideration of both timeliness and cost. "An international insight is a must for a mature global contractor", he insisted that international contractors should learn to be more adaptive and innovative. "If the project was undertaken in Africa, the better procurement choices may be working with French or German suppliers because of the closer distance, in particular for materials with shorter shelf life, such as explosive".

The importance of vacancies after final handover of a project is often underestimated. A retrospection of the whole delivery process should be encouraged to summarize both successful experience and lessons. With years of elaborate running of global business, Chinese contractors accumulated valuable industrial experience and resources, which should be carefully maintained. However, due to the fast liquidity of project staff and the lack of standardized procedures of knowledge transfer and storage, some precious lessons are merely verbally spread, which cannot be taken the most advantages of in future projects. A general engineer also expressed his concerns that past mistakes might be repeated, with which the contractor has to waste much time to deal. Time performance will be significantly improved of lessons about construction delays from previous projects can be transferred via an open channel.

Besides retrospection, the maintenance of long-term partnership with the participants after the final handover is also of great importance, agreed by the project manager of an infrastructure project in Ethiopia, as he found his second cooperation with the same consulting engineer much easier than the first one. "It saved us so much trouble and time. On the basis of our first cooperation, we do not have to explain to the consulting engineer about why we choose this method or material anymore, because our performance has earned his recognition". As a form of soft power, the recognition given by peers in the construction industry could bring much convenience in inter-organizational communication as the basis of the alliance is based on trust with each other.

\section{Conclusions}

\section{Findings}

As a dominant instrument to stimulate economic growth, global construction industry has witnessed a rapid growing demand for large social infrastructure and competent international contractor (Alotaibi, 2018). Time overrun, one of the most common issues in international project delivery, has attracted worldwide attention as a result of its serious adverse effect on project performance and the participants (Marzouk et al., 2008). To evaluate the time performance of international projects and explore the root causes of construction delays, a case study approach was adopted to conduct both quantitative and qualitative analysis of evidence collected and identified from 112 international construction projects. Multiple correspondence analysis (MCA) and one-way analysis of variance (ANOVA) were combined to assess and compare time performance among the cases. Then, the results of focus group interviews helped validate the statistical tests and more importantly, identify the root causes of construction delays in the 112 cases. The main findings of the study include:

1) The results of multiple correspondence analysis show that international project time performance is related with project metrics including project location, project designer, project cost, project type, delivery method, technical standard and contractor size.

2) Chinese contractors achieve significantly better time performance in Asia and Africa, compared with that in Latin America. Doing business in Asia means fewer language barriers and potential conflicts due to similar social and cultural backgrounds. Besides, delivery of domestically procured equipment and raw materials is much faster, facilitating better time performance.

3) Chinese contractors perform significantly better in large-scale projects in contrast with small-sized projects. The reason lies in not only Chinese contractors' technical proficiency in delivering large-scale projects but also the fact that the output of largescale projects produced by management activities per unit input of manpower, materials, equipment and money is beyond comparison of small-sized projects. 
4) Chinese contractors achieve significantly better time performance in power projects in contrast with general projects and transportation projects. One contributing cause is the wealth of Chinese contractors' experience and technologies inherited from previous power projects. Another is that the long contract duration of power projects can accommodate the project team with enough time for multiple participants to adapt to one another in management style and communication patterns at early stage, thus establishing an integral coordination mechanism based on trust during the rest of time.

5) The results of focus group interviews illustrate that the root causes of international construction delays can be categorized into two types: managementrelated factors (interface, human resources, design and procurement) and environment-related factors (cultural, social, natural, technical and legal). Both deficiency in internal management and inadaptation to external environments have become major constraints for international contractors to improve time performance.

6) On the basis of above insights, strategies to improve international project time performance include: conducting in-depth pre-investigations, involving international firms and professionals, encouraging cross-cultural dialogues, integrating global resources, establishing long-term global partnership and valuing timely documenting and assessments.

\section{Theoretical and practical contributions}

Based on existing studies and international construction practice, this study is mapping time performance on international project management, project environments and global partnership by drawing a holistic picture. The theoretical and practical contributions include:

Firstly, this study identified the distinctive characteristics of three types of projects (late, acceptable, early) classified according to their time performances, drawing an overall picture of international project performance and its association with influential factors. Secondly, this study compared the project time performances categorized according to project location, project designer, project cost and project type, confirming that international project time performance is significantly related to the contractor's adaptability and the project's complexity. Thirdly, this study revealed the root causes of construction delays in international project delivery, which provides a structured and in-depth understanding of both internal and external time performance influential factors. Fourthly, the above findings provide sound basis for guiding practitioners in choosing appropriate strategies on management of international projects to continuously improve project time performance.

\section{Limitations and future research directions}

Despite both important theoretical and practical implications, there are still some limitations of this study. Firstly, the samples were all collected from Chinese SOEs, while the contributions of contractors from other countries. Secondly, only time performance was taken into consideration in this study. As a matter of fact, indexes, such as quality, cost and stakeholder satisfaction, should be introduced in future research to better measure project success. Further research is also encouraged to explore the difference of doing business in developed and developing countries to facilitate a more comprehensive perception of international project delivery.

\section{List of abbreviations}

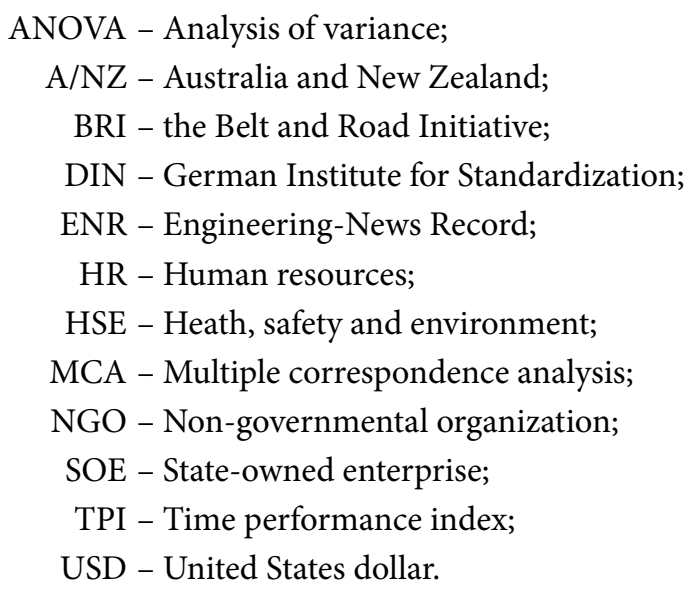

\section{Acknowledgements}

We would like to thank the National Natural Science Foundation of China (Grant Nos. 72171128, 51579135, 51779124), the State Key Laboratory of Hydroscience and Engineering (Grant Nos. 2015-KY-5 and 2013-KY-5) and Major Science and Technology Research Project of Power China (Grant Nos. DJ-ZDZX-2015-01-02, DJ-ZDZX-2015-01-07). Sincere gratitude is also shown to The University of Melbourne for the visiting scholar program. Last but not least, the participation of Chinese construction enterprises and project management experts involved in the case study and field survey is also much appreciated.

\section{References}

Abd El-Razek, M. E., Bassioni, H. A., \& Mobarak, A. M. (2008). Causes of delay in building construction projects in Egypt. Journal of Construction Engineering and Management, 134(11), 831-841.

https://doi.org/10.1061/(ASCE)0733-9364(2008)134:11(831)

Adekunle, O., \& Ajibola, W. K. (2015). Factorial causative assesments and effects of building construction project delays in Osun state, Nigeria. Journal of Architectural Engineering Technology, 4(3), 1-8. https://doi.org/10.4172/2168-9717.1000150 
Ahmed, S. M., Azhar, S., Castillo, M., \& Kappagantula, P. (2002). Construction delays in Florida: An empirical study. Department of Community Affairs, Florida, US.

Akinsiku, O. E., \& Akinsulire, A. (2012). Stakeholders' perception of the causes and effects of construction delays on project delivery. Journal of Construction Engineering and Project Management, 2(4), 25-31.

https://doi.org/10.6106/JCEPM.2012.2.4.025

Al-Sultan, A.S. (1989). Determination of construction contract duration for public projects in Saudi Arabia [Doctoral dissertation]. King Fahd University of Petroleum and Minerals.

Al-Kharashi, A., \& Skitmore, M. (2009). Causes of delays in Saudi Arabian public sector construction projects. Construction Management and Economics, 27(1), 3-23. https://doi.org/10.1080/01446190802541457

Al Tabtabai, H. M. (2002). Causes for delays in construction projects in Kuwait. Engineering Journal of Qatar University, $15,19-37$.

Ali, F., Dissanayake, D., Bell, M., \& Farrow, M. (2018). Investigating car users' attitudes to climate change using multiple correspondence analysis. Journal of Transport Geography, 72, 237-247. https://doi.org/10.1016/j.jtrangeo.2018.09.007

Alinaitwe, H., Apolot, R., \& Tindiwensi, D. (2013). Investigation into the causes of delays and cost overruns in Uganda's public sector construction projects. Journal of Construction in Developing Countries, 18(2), 33-47.

Alotaibi, N. O. M. (2018). Managing critical factors causing delays in public construction projects in the Kingdom of Saudi Arabia [Doctoral dissertation]. Curtin University.

Ameh, O. J., Soyingbe, A. A., \& Odusami, K. T. (2010). Significant factors causing cost overruns in telecommunication projects in Nigeria. Journal of Construction in Developing Countries, 15(2), 49-67.

Anastasopoulos, P. C., Labi, S., Bhargava, A., \& Mannering, F. L. (2012). Empirical assessment of the likelihood and duration of highway project time delays. Journal of Construction Engineering and Management, 138(3), 390-398. https://doi.org/10.1061/(ASCE)CO.1943-7862.0000437

Anderson, G., Anderson, G. J., \& Arsenault, N. (1998). Fundamentals of educational research. RoutledgeFalmer.

Arditi, D., Akan, G. T., \& Gurdamar, S. (1985). Reasons for delays in public projects in Turkey. Construction Management and Economics, 3(2), 171-181.

https://doi.org/10.1080/01446198500000013

Asnaashari, E., Knight, A., Hurst, A., \& Farahani, S. S. (2009). Causes of construction delays in Iran: Project management, logistics, technology and environment. In Proceedings of 25th Annual ARCOM Conference, Nottingham, UK.

Bhandari, S., \& Hallowell, M. R. (2021). Identifying and controlling biases in expert-opinion research: Guidelines for variations of Delphi, Nominal group technique, and focus groups. Journal of Management in Engineering, 37(3), 04021015. https://doi.org/10.1061/(ASCE)ME.1943-5479.0000909

Chen, Y. Q., Liu, J. Y., Li, B., \& Lin, B. (2011). Project delivery system selection of construction projects in China. Expert Systems with Applications, 8(5), 5456-5462. https://doi.org/10.1016/j.eswa.2010.10.008

Cho, K. M., Hong, T. H., \& Hyun, C. T. (2009). Effect of project characteristics on project performance in construction projects based on structural equation model. Expert Systems with Applications, 36(7), 10461-10470.

https://doi.org/10.1016/j.eswa.2009.01.032

Cox, R. F., Issa, R. R. A., \& Ahrens, D. (2003). Management's perception of key performance indicators for construction.
Journal of Construction Engineering and Management, 129(2), 142-151.

https://doi.org/10.1061/(ASCE)0733-9364(2003)129:2(142)

Dhalmahapatra, K., Shingade, R., Mahajan, H., Verma, A., \& Maiti, J. (2019). Decision support system for safety improvement: an approach using multiple correspondence analysis, t-SNE algorithm and K-means clustering. Computers \& Industrial Engineering, 128, 277-289.

https://doi.org/10.1016/j.cie.2018.12.044

Engineering News-Record. (2014). The global sourcebook. McGraw Hill.

Engineering News-Record. (2015). The global sourcebook. McGraw Hill.

Engineering News-Record. (2016). The global sourcebook. McGraw Hill.

Engineering News-Record. (2017). The global sourcebook. McGraw Hill.

Engineering News-Record. (2018). The global sourcebook. McGraw Hill.

Faridi, A. S., \& El-Sayegh, S. M. (2006). Significant factors causing delay in the UAE construction industry. Construction Management and Economics, 24(11), 1167-1176.

https://doi.org/10.1080/01446190600827033

Frimpong, Y., Oluwoye, J., \& Crawford, L. (2003). Causes of delay and cost overruns in construction of groundwater projects in a developing countries: Ghana as a case study. International Journal of Project Management, 21(5), 321-326. https://doi.org/10.1016/S0263-7863(02)00055-8

Gillham, B. (2000). Case study research methods. Bloomsbury Publishing.

Gonzalez, P., González, V., Molenaar, K., \& Orozco, F. (2014). Analysis of causes of delay and time performance in construction projects. Journal of Construction Engineering and Management, 140(1), 4013027.

https://doi.org/10.1061/(ASCE)CO.1943-7862.0000721

Gunduz, M., \& AbuHassan, M. H. (2016). Causes of construction delays in Qatar construction projects. International Journal of Civil Engineering, 10(4), 531-536.

Gunhan, S., \& Arditi, D. (2005). Factors affecting international construction. Journal of Construction Engineering and Management, 131(3), 273-282.

https://doi.org/10.1061/(ASCE)0733-9364(2005)131:3(273)

Hasan, R. A. M. (2014). An investigation into the delays in road projects in Bahrain [Doctoral dissertation]. University of Bahrain.

Haseeb, M., Bibi, A., \& Rabbani, W. (2011). Problems of projects and effects of delays in the construction industry of Pakistan. Australian Journal of Business and Management Research, 1(5), 41-50.

https://doi.org/10.52283/NSWRCA.AJBMR.20110106A05

Hossain, M. S., Rahim, N. A., Aman, M. M., \& Selvaraj, J. (2019). Application of ANOVA method to study solar energy for hydrogen production. International Journal of Hydrogen Energy, 44(29), 14571-14579.

https://doi.org/10.1016/j.ijhydene.2019.04.028

IBM. (2020). Transforming variable to normality for parametric statistics. https://www.ibm.com/support/pages/transformingvariable-normality-parametric-statistics

Javernick-Will, A. N., \& Scott, W. R. (2010). Who needs to know what? Institutional knowledge and global projects. Journal of Construction Engineering and Management, 136(5), 546-557. https://doi.org/10.1061/(ASCE)CO.1943-7862.0000035

Jobson, J. D. (2012). Applied multivariate data analysis. Volume II: Categorical and multivariate methods. Springer Science \& Business Media. 
Kadry, M., Osman, H., \& Georgy, M. (2017). Causes of construction delays in countries with high geopolitical risks. Journal of Construction Engineering and Management, 143(2), 04016095. https://doi.org/10.1061/(ASCE)CO.1943-7862.0001222

Kaka, A., \& Price, A. D. F. (1991). Relationship between value and duration of construction projects. Construction Management and Economics, 9(4), 383-400.

https://doi.org/10.1080/01446199100000030

Kaliba, C., Muya, M., \& Mumba, K. (2009). Cost escalation and schedule delays in road construction projects in Zambia. International Journal of Project Management, 27(5), 522-531. https://doi.org/10.1016/j.ijproman.2008.07.003

Kazaz, A., Ulubeyli, S., \& Tuncbilekli, N. A. (2012). Causes of delays in construction projects in Turkey. Journal of Civil Engineering and Management, 18(3), 426-435.

https://doi.org/10.3846/13923730.2012.698913

Khoshgoftar, M., Bakar, A. H. A., \& Osman, O. (2010). Causes of delays in Iranian construction projects. International Journal of Construction Management, 10(2), 53-69.

https://doi.org/10.1080/15623599.2010.10773144

Kikwasi, G. (2012). Causes and effects of delays and disruptions in construction projects in Tanzania. Australasian Journal of Construction Economics and Building (Conference Series), 1(2), 52-59. https://doi.org/10.5130/ajceb-cs.v1i2.3166

Kim, Y.-M., Kim, S.-Y., \& Luu, T.-V. (2008). Causes of construction delays of apartment construction projects: Comparative analysis between Vietnam and Korea. Korean Journal of Construction Engineering and Management, 9(5), 214-226.

Koushki, P. A., \& Kartam, N. (2004). Impact of construction materials on project time and cost in Kuwait. Engineering, Construction and Architectural Management, 11(2), 126-132. https://doi.org/10.1108/09699980410527867

Latham, S. M. (1994). Constructing the team. HSMO, London.

Le-Hoai, L., Dai Lee, Y., \& Lee, J. Y. (2008). Delay and cost overruns in Vietnam large construction projects: A comparison with other selected countries. KSCE Journal of Civil Engineering, 12(6), 367-377.

https://doi.org/10.1007/s12205-008-0367-7

Lei, Z., Tang, W., Duffield, C., Zhang, L., \& Hui, F. K. P. (2017). The impact of technical standards on international project performance: Chinese contractors' experience. International Journal of Project Management, 35(8), 1597-1607. https://doi.org/10.1016/j.ijproman.2017.09.002

Liu, A., Lu, C., \& Wang, Z. (2020). The roles of cultural and institutional distance in international trade: Evidence from China's trade with the Belt and Road countries. China Economic Review, 61, 101234.

https://doi.org/10.1016/j.chieco.2018.10.001

Mahalingam, A., \& Levitt, R. E. (2007). Institutional theory as a framework for analyzing conflicts on global projects. Journal of Construction Engineering and Management, 133(7), 517-528. https://doi.org/10.1061/(ASCE)0733-9364(2007)133:7(517)

Male, S. (2003). Faster building for commerce: NEDO (1988). In M. Murray, \& D. Langford (Eds), Construction reports 194498 (pp. 130-144). Blackwell Publishing. https://doi.org/10.1002/9780470758526.ch10

Marzouk, M., El-Dokhmasey, A., \& El-Said, M. (2008). Assessing construction engineering-related delays: Egyptian perspective. Journal of Professional Issues in Engineering Education and Practice, 134(3), 315-326.

https://doi.org/10.1061/(ASCE)1052-3928(2008)134:3(315)

Merrow, E. W. (2011). Industrial megaprojects. Wiley. https://doi.org/10.1002/9781119201045
Mezher, T. M., \& Tawil, W. (1998). Causes of delays in the construction industry in Lebanon. Engineering, Construction and Architectural Management, 5(3), 252-260.

https://doi.org/10.1108/eb021079

Molugaram, K., Rao, G. S., Shah, A., \& Davergave, N. (2017). Statistical techniques for transportation engineering. Butterworth-Heinemann.

Odeyinka, H. A., Oladapo, A., \& Dada, J. O. (2004). An assessment of risk in construction in the Nigerian construction industry. In International Symposium on Globalisation and Construction (pp. 359-368).

Ogunlana, S. O., Promkuntong, K., \& Jearkjirm, V. (1996). Construction delays in a fast-growing economy: comparing Thailand with other economies. International Journal of Project Management, 14(1), 37-45.

https://doi.org/10.1016/0263-7863(95)00052-6

Orozco, F. A., Serpell, A. F., Molenaar, K. R., \& Forcael, E. (2014). Modeling competitiveness factors and indexes for construction companies: Findings of Chile. Journal of Construction Engineering and Management, 140(4), B4013002. https://doi.org/10.1061/(ASCE)CO.1943-7862.0000462

Othman, A. A., Torrance, J. V., \& Hamid, M. A. (2006). Factors influencing the construction time of civil engineering projects in Malaysia. Engineering, Construction and Architectural Management, 13(5), 481-501.

https://doi.org/10.1108/09699980610690756

Pourrostam, T., \& Ismail, A. (2011). Study of methods for minimizing construction delays: Evidences from a developing country. Advanced Materials Research, 201-203, 29392942. https://doi.org/10.4028/www.scientific.net/AMR.201203.2939

Ramcharran, H. (1998). Obstacles and opportunities in international engineering services. Journal of Management in Engineering, 14(5), 38-47.

https://doi.org/10.1061/(ASCE)0742-597X(1998)14:5(38)

Rahman, I. A., Memon, A. H., Nagapan, S., Latif, Q. B. A. I., \& Azis, A. A. A. (2012). Time and cost performance of costruction projects in southern and cenrtal regions of Penisular Malaysia. In 2012 IEEE Colloquium on Humanities, Science and Engineering (CHUSER) (pp. 52-57), Kota Kinabalu, Malaysia. https://doi.org/10.1109/CHUSER.2012.6504280

Richards, G., \& van der Ark, L. A. (2013). Dimensions of cultural consumption among tourists: Multiple correspondence analysis. Tourism Management, 37, 71-76. https://doi.org/10.1016/j.tourman.2013.01.007

Rwelamila, P. D., \& Hall, K. A. (1995). Total systems intervention: an integrated approach to time, cost and quality management. Construction Management and Economics, 13(3), 235-241. https://doi.org/10.1080/01446199500000027

Sambasivan, M., \& Soon, Y. W. (2007). Causes and effects of delays in Malaysian construction industry. International Journal of Project Management, 25(5), 517-526. https://doi.org/10.1016/j.ijproman.2006.11.007

Sambasivan, M., Deepak, T. J., Salim, A. N., \& Ponniah, V. (2017). Analysis of delays in Tanzanian construction industry. Engineering, Construction and Architectural Management, 24(2), 308-325. https://doi.org/10.1108/ECAM-09-2015-0145

Santoso, D. S., \& Soeng, S. (2016). Analyzing delays of road construction projects in Cambodia: Causes and effects. Journal of Management in Engineering, 32(6), 05016020. https://doi.org/10.1061/(ASCE)ME.1943-5479.0000467

Seboru, M. A. (2006). An investigation into factors causing delays in road construction projects in Kenya [Doctoral dissertation]. University of Nairobi. 
Seboru, M. A. (2015). An investigation into factors causing delays in road construction projects in Kenya. American Journal of Civil Engineering, 3(3), 51-63.

https://doi.org/10.11648/j.ajce.20150303.11

Semple, C., Hartman, F. T., \& Jergeas, G. (1994). Construction claims and disputes: causes and cost/time overruns. Journal of Construction Engineering and Management, 120(4), 785-795. https://doi.org/10.1061/(ASCE)0733-9364(1994)120:4(785)

Smalheiser, N. (2017). Data literacy: How to make your experiments robust and reproducible. Academic Press.

Talukhaba, A. A. (1999). An investigation into factors causing construction project delays in Kenya [Doctoral dissertation]. University of Nairobi.

Toor, S., \& Ogunlana, S. O. (2008). Problems causing delays in major construction projects in Thailand. Construction Management and Economics, 26(4), 395-408.

https://doi.org/10.1080/01446190801905406

Walker, D. H. T. (1995). An investigation into construction time performance. Construction Management and Economics, 13(3), 263-274. https://doi.org/10.1080/01446199500000030

World Bank. (2019). Belt and road economics: Opportunities and risks of transport corridors. Washington, DC, USA.

Wright, J. N. (1997). Time and budget: The twin imperatives of a project sponsor. International Journal of Project Management, 15(3), 181-186. https://doi.org/10.1016/S0263-7863(96)00059-2

Yin, R. K. (2017). Case study research and applications: Design and methods. SAGE Publishing. 